\title{
РОздІМ 3
}

\section{Мiкроекономічні механізми}

\section{Small and Medium Entrepreneurship: Ukrainian and World Experience}

\author{
Daria D. TymoshyK ${ }^{i}$, Larysa L. Hrytsenko ${ }^{i i}, Y_{\text {aroslav S. Kovalev }}$ iii
}

The article considers the concept of small and medium enterprises in the process of economic thought formation. The task of the work is to determine and analyze the state of small and medium business in Ukraine and abroad. For this, the definitions of foreign and national scholars are outlined and their own understanding of the term is formulated. A comparative and quantitative analysis of enterprises was conducted on the basis of data collected by the State Statistics Service of Ukraine, and a positive increase in enterprises for the period 2014-2018 was revealed. In addition, the main approaches to the division of enterprises into types according to different classification criteria due to the Ukrainian economic system and the standards of the European Union, which fundamentally differ from the division system in the United States, are studied. At the same time, the indicators of small and medium-sized enterprises of the USA and European countries are considered, that allows us to say that the largest percentage of the contribution to GDP belongs to the small and medium-sized enterprise sector. The described features of SMEs in comparison with other types of enterprises determine the importance of SMEs as a stable and self-sufficient sector of the economy which requires support from government regulation.

The urgency of research on the topic of SMEs is primarily dictated by the need to summarize the previously studied layers of this topic, the emergence of new reforms and Ukraine's desire to improve the economic system and bring it to the world level.

Economic development depends not only on internal policy principles, but also on external factors influencing the state of the world economy. The beginning of 2020 made the leaders of the world community think about the principles of maintaining economic indicators during the trigger caused by the coronavirus pandemic and the collapse of oil prices, and therefore it is natural to implement programs to support small and medium enterprises during the global recession.

Keywords: types of enterprises, small and medium enterprises, national entrepreneurship, entrepreneurship, role of small and medium entrepreneurship, economic entities.

Introduction. Small and medium entrepreneurship (hereinafter - SME) plays an important role in solving economic and social problems. It is SME that contributes to the markets

${ }^{i}$ Daria D. Tymoshyk, Postgraduate Student of the Department of Finance and Entrepreneurship, Sumy State University;

${ }^{i i}$ Larysa L. Hrytsenko, Doctor of Economics, Professor of the Department of Finance and Entrepreneurship, Sumy State University, Sumy;

iii Yaroslav S. Kovalev, Postgraduate Student of the Department of Economics, Entrepreneurship and Business Administration, Sumy State University.

(C) D. D. Tymoshyk, L. L. Hrytsenko, Ya. S. Kovalev, 2020.

https://doi.org/10.21272/mer.2020.88.07 
Daria D. Tymoshyk, Larysa L. Hrytsenko, Yaroslav S. Kovalev Small and Medium Entrepreneurship: Ukrainian and World Experience

optimization and structuring, ensure the supply and demand elasticity, mobilize national resources, stimulate the preservation of national market potential. At the same time, the quality jobs creation, competition possibility, lower unemployment, increase the number of employed people, living conditions improvement, innovative development intensification, etc. are the number of tasks that can be implemented only in terms of sustainable entrepreneurship development. The level of SME is a kind of the state indicator of national economy, as the flexible nature of this economic sector allows you to respond actively and quickly to social changes and changes in market conditions.

Recent studies and publications analysis. R. Cantillon was the first who attempted to theoretically generalize and define the concept of entrepreneurship. A lot of foreign scholars have studied the term of entrepreneurship. They are A. Smith, J.-B. Sei, A. Marshall, J. Schumpeter, M. Weber, K. McConnell, S. Brew, and others. Peculiarities and problems of national entrepreneurship development are also considered by national scientists, such as A. Danylenko, A. Melnyk, V. Miklovda, Z. Varnalii, M. Kozoriz, M. Dolishnii, S. Mochernyi, S. Reverchuk and others.

However, despite the significant number of scientific works on this topic, there is a need to generalize theoretical concepts on the division of enterprises into types and the definition of small and medium enterprises.

The purpose of the article is to study and generalize the concept of entrepreneurship in economic theory and determine the role of small and medium entrepreneurship in the social and economic development of the country.

The study's results. The concept of entrepreneurship is contradictory because it is a "phenomenon of social life, developing in a certain social, economic and historical environment" [1], and therefore, its interpretation depends on the aspects and approaches taken as a basis.

The first theoretical substantiation of the studied term was offered by R. Cantillon. The scientist described entrepreneurship as an innovative activity directly related to risk, and the entrepreneur as a person "who at a certain price buys the means of production to produce products and sells it for income, and who, committing to costs, does not know at what prices the production can be realized" [2]. This comprehension became the basis for further understanding of the concept in economic theory.

Theorists and practitioners A. Smith, J.-B. Sei, A. Marshall, M. Weber and others studied various economic aspects, linked business with management, identified capital owners and businessmen, centralized the figure of the entrepreneur in the economic process, and so on. For example, K. McConnell and S. Brew defined entrepreneurship as a special activity in which the entrepreneur plays an intermediary role, combines land resources, capital and labor into one production process and takes responsibility for enterprise development, not forgetting about the risk probability [3].

However, the main concept in the development of the theoretical basis of entrepreneurship is considered to be the J. Schumpeter's theory. In his opinion, entrepreneurship is a universal function of the economic system, the purpose of which is to design innovative combinations, combining different activities [4]. The concept interpretation of entrepreneurship should include a combination of three main principles:

- implementation of new combinations of production factors;

- combination of business functions with other activities;

- taking into account the economic and political environment, which determines the opportunities, types, motivations of entrepreneurship. 
American scientists E. Dolan and D. Lindsay have repeatedly emphasized that the main purpose of entrepreneurship is to find new opportunities and methods of production, move away from old strategies and implement new promising methods and improve the organization of economic activity [5]. Therefore, innovation and innovative approach have become the basis for defining the entrepreneurship of various researchers.

Systematization of the main scientific and methodological approaches to the definition of entrepreneurship and the interpretation of this term at the legislative level are given in Table 1.

Approaches to the definition of "Entrepreneurship"

Table 1

\begin{tabular}{|l|l|}
\hline \multicolumn{1}{|c|}{ Author, Source } & \multicolumn{1}{|c|}{ The definition of the notion "Entrepreneurship" } \\
\hline L. Vorotina [14] & $\begin{array}{l}\text { Entrepreneurship is not any activity of a manufacturer, banker, trade } \\
\text { worker, service sector, but only the activity of the owner, who } \\
\text { independently or with the involvement of hired labor begins and } \\
\text { carries out production, trade, etc. }\end{array}$ \\
\hline $\begin{array}{l}\text { R. Trynko, } \\
\text { O. Malinovska [8] }\end{array}$ & $\begin{array}{l}\text { Entrepreneurship is an economic entrepreneur's resource with four key } \\
\text { functions being in continuous interaction: the combination of land, } \\
\text { capital and labor resources in a single production process of goods and } \\
\text { services; independent decision-making; innovative approach and risk } \\
\text { in activity }\end{array}$ \\
\hline J. Nikolenko [9] & $\begin{array}{l}\text { Entrepreneurship is a certain system of enterprises life-sustaining } \\
\text { activity, which is based on democratic forms of their economic } \\
\text { activity, providing them with the right of initiative in choosing the } \\
\text { field, forms, management methods, economic, organizational and } \\
\text { technical creativity and innovation }\end{array}$ \\
\hline Z. Varnalii [10] & $\begin{array}{l}\text { Entrepreneurship is an initiative, independent, innovative, systematic } \\
\text { activity of production, work, services provision, which is carried out } \\
\text { at your own risk and under personal property responsibility in order to } \\
\text { obtain entrepreneurial income }\end{array}$ \\
\hline $\begin{array}{l}\text { Law of Ukraine "On } \\
\text { Entrepreneurship" [6] }\end{array}$ & $\begin{array}{l}\text { Entrepreneurship is defined as a direct independent, systematic, at } \\
\text { their own risk activities for the goods production, work, services } \\
\text { provision for profit, which is carried out by individuals and legal } \\
\text { entities registered as business entities in the manner prescribed by law }\end{array}$ \\
\hline $\begin{array}{l}\text { Economic Code of } \\
\text { Ukraine [7] }\end{array}$ & $\begin{array}{l}\text { Entrepreneurship is an independent, proactive, systematic, at your own } \\
\text { risk economic activity carried out by business entities (entrepreneurs) } \\
\text { in order to achieve economic and social results and make a profit }\end{array}$ \\
\hline
\end{tabular}

The analysis of different approaches to the definition of entrepreneurship allowed us to conclude that the most complete and well-argued interpretation belongs to Z. Varnalii, which is that "entrepreneurship as an economic category is a certain type of management in which the main subject is an entrepreneur who rationally combines factors of production, on an innovative basis and at its own risk organizes and manages production in order to obtain entrepreneurial income" [10].

Thus, entrepreneurship is an initiative, independent, systematic type of activity carried out by business entities at their own risk and property responsibility to achieve results and obtain entrepreneurial profits.

In modern economic theory, there are many classifications for the business entities division depending on key criteria (Table 2). The scope of our study is the division of business entities into micro, small, medium and large enterprises. 
Daria D. Tymoshyk, Larysa L. Hrytsenko, Yaroslav S. Kovalev Small and Medium Entrepreneurship: Ukrainian and World Experience

Table 2

Classification of enterprises in Ukraine

(formed on the basis of [11])

\begin{tabular}{|l|l|}
\hline \multicolumn{1}{|c|}{ Separation Criterion } & \multicolumn{1}{c|}{ Types of Enterprises } \\
\hline Form of incorporation & private, employee-owned, state, public utility \\
\hline Range of activity & micro, small, medium and large \\
\hline Way of creation and forming the statutory fund & unitary, corporate \\
\hline $\begin{array}{l}\text { Technologic integrity and degree of } \\
\text { subordination }\end{array}$ & main, subsidiary, associated, branch office \\
\hline Corporate objective and nature of activity & $\begin{array}{l}\text { entrepreneurial / commercial, } \\
\text { gsocial / uncommercial }\end{array}$ \\
\hline Capital & national, foreign, utility \\
\hline Legal status and business pattern & $\begin{array}{l}\text { sole proprietorship, cooperative, partnership, } \\
\text { lease holding }\end{array}$ \\
\hline Industrial and functional kind of activity & $\begin{array}{l}\text { industrial, agricultural, bank, transport, leasing, } \\
\text { insurance, etc. }\end{array}$ \\
\hline
\end{tabular}

For the first time, the division of enterprises depending on the range of activity was defined by the Law of Ukraine "On Entrepreneurship" in 1991. Subsequently, the legislation was improved due to the growth of the enterprises number and changes in the economic, political and social life of the country.

Separation criterion for enterprises to a particular type are correlated with the general level of the country's economy. In addition, the definition of SME requires consideration not only of quantitative criteria (manning level, amount of annual income, book value, etc.), but also qualitative characteristics (legal independence, unity of ownership and direct firm management, the direct nature of the employer-employee relationship; responsibility for business results; small market, etc.) [10]. It should be noted that at this stage of the study we consider only quantitative indicators.

Therefore, in the latest version of the Law of Ukraine № 2164-VIII dated October 5, 2017 on amendments to the Law of Ukraine "On Accounting and Financial Reporting in Ukraine (to improve some provisions)" [12] the division of business entities depends on the average number of employees, sales income and book value of assets.

Table 3

Business entities division

(formed on the basis of [12])

\begin{tabular}{|l|l|l|l|}
\hline \multicolumn{1}{|c|}{ Types of enterprises } & \multicolumn{1}{c|}{ Total stuffing } & \multicolumn{1}{c|}{ Sales income } & Book value \\
\hline Small enterprises & up to 50 people & up to 8 million euro & up to 4 million euro \\
\hline Medium enterprises & up to 250 people & up to 40 million euro & up to 20 million euro \\
\hline
\end{tabular}

The European division system is mainly based on the Commission Recommendation of 2003 [13], which prioritizes the number of employees.

Based on the above-mentioned information, small and medium enterprises are organizational and economic types of enterprises, which have a staff of 10 to 250 people, from 700 thousand euro to 40 million euro of annual income, from 350 thousand euro to 20 million euro of book value and direct its independent innovation to profit. 
Business entities division in Europe (formed on the basis of [13])

\begin{tabular}{|l|l|l|l|}
\hline \multicolumn{1}{|c|}{ Types of enterprises } & Total stuffing & Sales income & Book value \\
\hline Small enterprises & up to 50 people & up to 10 million euro & up to 10 million euro \\
\hline Medium enterprises & up to 250 people & up to 50 million euro & up to 43 million euro \\
\hline
\end{tabular}

According to the State Statistics Service of Ukraine, there are about 971 thousand legal entities in the country, excluding non-commercial organizational and legal forms of ownership, of which about 700 thousand are active [15].

Table 5

Number of business entities divided into large, medium, small and micro enterprises (formed on the basis of [15])

\begin{tabular}{|c|c|c|c|c|}
\hline Year & $\begin{array}{c}\text { Total amount of } \\
\text { enterprises }\end{array}$ & $\begin{array}{c}\text { Large } \\
\text { enterprises }\end{array}$ & $\begin{array}{c}\text { Medium } \\
\text { enterprises }\end{array}$ & $\begin{array}{c}\text { Small } \\
\text { enterprises }\end{array}$ \\
\hline 2018 & 355877 & 446 & 16057 & 339374 \\
\hline 2017 & 338256 & 399 & 14937 & 322920 \\
\hline 2016 & 306369 & 383 & 14832 & 291154 \\
\hline 2015 & 343440 & 423 & 15203 & 327814 \\
\hline 2014 & 341001 & 497 & 15906 & 324598 \\
\hline
\end{tabular}

The analysis of the State Statistics Service data confirms that small and medium-sized enterprises make up the main points of business. Since 2014, there has been a certain quantitative decrease, but changes in legislative documents, especially in the Law of Ukraine "On Limited and Additional Liability Companies", adopted in 2018, contribute to the emergence of enterprises directly related to providing greater freedom in corporate structure management and obtaining less regulatory control. Therefore, as at the date of 2018, the percentage of SMEs is $99.9 \%$ of the total number of enterprises (including micro-enterprises). It is also important to note that the percentage of employees in small and medium enterprises is $73.5 \%$ of the total number of employees. For comparison, the percentage of employees in large enterprises is $26.4 \%$

In 2019, a member of the reform support team of the Ministry of Economic Development and Trade of Ukraine D. Shemyakin noted that the contribution of small and medium-sized businesses to GDP is $55 \%$, and large and medium - $73 \%$. In Europe - twice as much. The number of enterprises does not affect efficiency and productivity.

Supporting the SMEs development is one of the concepts of economic development of European countries. Thus, the SME group is the foundation of the German economy, which covers $99 \%$ of all companies in the country. According to the German Federal Ministry of Economics and Energy, small and medium-sized enterprises can provide $60 \%$ workplaces and produce more than $50 \%$ of all production.

According to the European Information and Research Center, as at the date of 2018, about 3 million small and medium-sized enterprises are registered in France, and the share of SMEs in GDP is $50 \%$. In the UK, small and medium-sized businesses account for $96 \%$ and produce $20 \%$ of GDP. Italy is the leading country in Europe in the number of SMEs (more than 3.6 million companies). 
Daria D. Tymoshyk, Larysa L. Hrytsenko, Yaroslav S. Kovalev Small and Medium Entrepreneurship: Ukrainian and World Experience

Spain is no exception: $99.8 \%$ of the total number of enterprises are SMEs, although $97 \%$ of enterprises have a profit of less than 2 million euro, and $95.8 \%$ of enterprises employ up to 9 people. This allows us to talk about the national specifics of the Spanish economy.

If in the European Union enterprises with the amount of 250 employees are considered to be small and medium-sized businesses, in the United States SMEs can have up to 1.200 employees. According to data from 2018, recorded by the US Small Business Administration, $99.9 \%$ of enterprises were small, which once again indicates the important role of SMEs in economic growth.

Trends in the modern economy dictate to states the conditions for creating sustainable SME development. Small and medium enterprises are characterized by a flexible organizational and managerial structure. A small number of employees requires the introduction of the principles of interchangeability and universality of specialists, that minimizes financial and labor resources, that cannot be said about large enterprises. Possible changes in demand do not usually cause ruin, as new consumer needs encourage business owners to restructure and they are able to offer new products in the short term.

SMEs do not need large start-up capital, while providing part of the population with workplaces. And this primarily means the formation of the middle class, which is the basis of economic and social status. Of course, SMEs are more favorable and vulnerable to external risks such as inflation, price fluctuations, credit conditions, changes in taxation, etc., but internal organization and flexible management create competition and contribute to the innovative development of the country as a whole.

Conclusions and prospects for further research. The concepts of entrepreneurship, small and medium enterprises are in the center of researchers' attention because of constant changes in the economic structure of the country. The example of the world economy gives the right to say, "that small, medium and large enterprises are not mutually exclusive, but complementary. The most important component of a market economy should be the existence and interaction of many large, medium and small enterprises, and the optimal ratio of them" [10]. SMEs take active part in macroeconomic and microeconomic processes and remain an indicator of structural changes in the national economy, and unfavorable business conditions and unsustainable development of the Ukrainian economy in general lead to a decrease in the number of large enterprises, that in turn may intensify the process of small and medium enterprises establishment.

A static review of the entrepreneurship state allows us to talk about the positive changes in the formation and development of small and medium enterprises in Ukraine. The growth in the number of SMEs is reflected in the level of employment, GDP level and total value added.

However, the spread of the COVID-19 pandemic has made adjustments. The introduction of quarantine measures has caused a number of social and economic problems: the closure of state borders, the suspension of imports and exports, falling oil prices, the closure of many enterprises or introducing a distance form of work, the cessation of transport, unemployment and more. Partial resumption of daily life still does not allow the economy to return to normal. For example, the increase in the coronavirus epidemic in the United States and the predicted second wave in autumn in the world as a whole require a reduction in oil production indefinitely, as a result of which the Kingdom of Saudi Arabia and the United Arab Emirates raise export prices. Therefore, according to analysts' opinion, the recession of the world economy will prevail at least until the end of 2020.

World governments develop and implement programs aimed at stabilizing the economic situation. The leaders of our country offered the program "Economic Recovery", which is 
intended for 2020-2022. The main goal of the program is to stimulate and restore the main sectors of the economy (agriculture, industry, services, etc.) and the economy as a whole.

European experience shows that competition encourages companies to develop and implement the latest technologies to improve production efficiency. This means the interdependence of the country's economy on the purposeful activities of SMEs. Therefore, the policy of our country should also be aimed at establishing a balance of interests of the state and business, providing optimal conditions for business, working out strategies and plans for the SMEs development, which in turn will lead to economic stability of Ukraine.

\section{References}

1. Varnalii, Z. (2005). Polityko-pravove rehuliivannia pidpryiemtsva $v$ Ukraini: teoriia i praktyka [Political and legal regulation of entrepreneurship in Ukraine: theory and practice]. Kyiv : Znannia [in Ukrainian].

2. Varnalii, Z. (2002). Osnovy pidpryiemnytstva [Fundamentals of entrepreneurship]. Kyiv : Znannia [in Ukrainian].

3. McConnell, K. R. \& Brew, S L. (2003). Ekonomiks: printsipyi, problemyi i politika [Economics: principles, problems and policies]. Moscow : INFRA-M [in Russian].

4. Schumpeter, J. (2008) Teoriya ekonomicheskogo razvitiya [Theory of economic development]. Moscow : Directmedia Publishing [in Russian].

5. Dolan, E. J., Lindsay, D. (1994). Mikroekonomika [Microeconomic]. Saint Petersburg [in Russian]

6. Zakon Ukrainy "Pro Pidpryiemnytstvo" [Law of Ukraine "On Entrepreneurship"]. Retrieved from https://zakon.rada.gov.ua/laws/show/698-12 [in Ukrainian].

7. Hospodarskyi kodeks Ukrainy [Economic Code of Ukraine]. Retrieved from https://zakon.rada.gov.ua/laws/show/436-15_[in Ukrainian].

8. Trynko, R. \& Malinovska, O. (2007) Derzhavne rehuliuvannia pidpryiemnytstva: teoriia, metodyka, praktyka [State regulation of entrepreneurship: theory, methodology, practice]. Lviv: Lvivskyi derzhavnyi universytet [in Ukrainian].

9. Nikolenko, Y. (eds.). (1992). Osnovy ekonomichnoi teorii: Pidpryiemnytstvo v rynkovii economitsi [Fundamentals of economic theory: Entrepreneurship in a market economy]. Kyiv: NMK VO [in Ukrainian].

10. Varnalii, Z. (2008) Male pidpryiemnytstvo: osnovy teorii i praktyky [Small business: foundations of theory and practice]. Kyiv : Znannia [in Ukrainian]

11. Rogach, S., Hutsul, T., \& Tkachuk, V. (2015). Ekonomika i pidpryiemnytstvo, menedzhment [Economics and entrepreneurship, management]. Kyiv: NUBiP Publishing Center of Ukraine [in Ukrainian].

12. Zakon Ukrainy pro vnesennia zmin do Zakonu Ukrainy "Pro bukhhalterskyi oblik ta finansovu zvitnist v Ukraini" shchodo udoskonalennia deiakykh polozhen [The Law of Ukraine on Amendments to the Law of Ukraine "On Accounting and Financial Reporting in Ukraine" concerning improvement of certain regulations]. Retrieved from https://zakon.rada.gov.ua/laws/show/2164 [in Ukrainian].

13. Rekomendatsiia Komisii vid 6 travnia 2003 roku pro vyznachennia mikro-, malykh ta serednikh pidpryiemstv [Commission Recommendation of 6 May 2003 on the definition of micro, small and medium-sized enterprises]. Retrieved from https://minjust.gov.ua/m/str_45877 [in Ukrainian].

14. Vorotina, L. I., Vorotin, V. E., Martyniuk, L. A. \& Cherniak, T. V. (2002). Malyi biznes ta pidpryiemnytstvo $v$ rynkovykh umovakh hospodariuvannia [Small business and entrepreneurship in a market economy]. Kyiv : Vydavnytstvo Yevropeiskoho universytetu [in Ukrainian].

15. State Statistical Service. Retrieved from http://ukrstat.gov.ua

Manuscript received 06 Fabuary 2020 
Daria D. Tymoshyk, Larysa L. Hrytsenko, Yaroslav S. Kovalev Small and Medium Entrepreneurship: Ukrainian and World Experience

Малое и среднее предпринимательство: украинский и мировой опыт

\title{
ДАРЬЯ ДМИТРИЕВНА ТиМОшИК*, ЛАРИСА ЛЕОНИДОВНА ГРИЦЕНКО Я РОСЛАВ СЕРГЕЕВИЧ КОВАЛЁВ
}

* аспирантка кафедры финансов и предпринимательства

Сумского государственного университета

ул. Римского-Корсакова, 2, г. Сумы, 40007, Украина,

тел.:00-380-50-2540415,e-mail:d.tymoshyk@study.sumdu.edu.ua

** доктор экономических наук, професор кафедры финансов и предпринимательства

Сумского государственного университета

ул. Римского-Корсакова, 2, г. Сумы, 40007, Украина,

тел.:00-380-50-3273004, e-mail: l.hrytsenko@finance.sumdu.edu.ua

\author{
*** аспирант кафедры экономики, предпринимательства и бизнес-администрирования \\ Сумского государственного университета, \\ ул. Р.-Корсакова, 2, г. Сумы, 40007, Украина, \\ тел:00-380-542-332223, e-mail: Litovec14@gmail.com
}

В статье рассмотрено понятие малого и среднего предпринимательства в процессе становления экономической мысли. Задача работы - определить и проанализировать состояние малого и среднего предпринимательства как в Украине, так и за рубежом. Для решения данной задачи нами были рассмотрены различные точки зрения зарубежных и отечественных ученых и сформулировано собственное понимание термина. Также был проведен сравнительноколичественный анализ предприятий на основе данных, собранных Государственной службой статистики Украины, и обнаружен положительный прирост предприятий за период 2014 2018 годов. Кроме того, исследованы основные подходы к классификации предприятий на виды по различным признакам согласно украинской экономической системе и стандартам Европейского Союза, которые коренным образом отличаются от классификации в США. Вместе с тем нами были рассмотрены показатели малого и среднего предпринимательства США и стран Европы, что позволяет говорить о том, что наибольший процент вклада в ВВП принадлежит именно сектору малого и среднего предпринимательства. Описанные особенности МСП в сравнении с другими видами предприятий определяют важность становления МСП как устойчивого и самодостаточного сектора экономики, который требуют поддержки со стороны государственного регулирования.

Актуальность исследования темы МСП прежде всего продиктована необходимостью обобщения ранее исследованных пластов данной тематики, появлением новых реформ и стремлением Украины усовершенствовать экономическую систему и вывести ее на мировой уровень.

Развитие экономики зависит не только от внутренних принципов ведения политики, но и от внешних факторов, влияющих на состояние мировой экономики. Начало 2020 года заставило руководителей стран мирового сообщества задуматься о принципах сохранения экономических показателей в период триггера, вызванного пандемией коронавируса и обвалом цен на нефть, а потому вполне закономерной является практика внедрения программ по поддержке предприятий малого и среднего бизнеса в период рецессии мировой экономики.

Ключевые слова: виды предприятий, малые и средние предприятия, национальное предпринимательство, предпринимательство, роль малого и среднего предпринимательства, субъекты хозяйствования.

Mechanism of Economic Regulation, 2020, No 2, 86-95

ISSN 1726-8699 (print) 
Д. Д. Тимошик, Л. Л. Гриценко, Я. С. Ковальов.

Мале та середнє підприємництво: український і міжнародний досвід

Мале та середнє підприємництво: український і міжнародний досвід

\section{ДаР'я Дмитрівна Тимошик", ЛАРИСА ЛЕОНІДІВНА ГРИЦЕНКО ЯрОсЛАв СЕРГІйович КовАЛЬов ${ }^{* * *}$}

* аспірантка кафедри фінансів і підприємницчтва

Сумського державного університету

вул. Римського-Корсакова, 2, м. Суми, 40007, Украӥна,

тел.:00-380-50-2540415,e-mail: d.tymoshyk@study.sumdu.edu.ua

** доктор економічних наук, професор кафедри фінансів і підприємництва

Сумського державного університету

вул. Римського-Корсакова, 2, м. Суми, 40007, Украӥна,

тел.:00-380-50-3273004, e-mail: l.hrytsenko@finance.sumdu.edu.ua

*** аспірант кафедри економіки, підприємництва та бізнес-адміністрування

Сумського державного університету

вул. Р.-Корсакова, 2, м. Суми, 40007, Украӥна,

тел:00-380-542-332223, e-mail:Litovec14@gmail.com

У статті розглянуто поняття малого та середнього підприємництва в процесі становлення економічної думки. Завдання роботи - визначити та проаналізувати стан малого та середнього підприємництва в Україні та закордоном. 3 цією метою окреслені визначення закордонних i національних науковців і сформульовано власне розуміння терміну. Проведено порівняльнокількісний аналіз підприємств на основі даних, зібраних Державною службою статистики України, і виявлений позитивний приріст підприємств за період 2014-2018 років. Окрім того досліджені основні підходи стосовно поділу підприємств на види за різними класифікаційними ознаками відповідно до української економічної системи та стандартів Свропейського Союзу, що докорінно відрізняються від системи поділу в Сполучених Штатах Америки. Разом 3 тим розглянуті показники малого та середнього підприємництва США і країн Свропи, що дозволяє говорити про те, що найбільший відсоток внеску у ВВП належить саме сектору малого та середнього підприємництва. Описані особливості МСП у порівнянні з іншими видами підприємств визначають важливість становлення МСП як стійкого та самодостатнього сектору економіки та вимагають підтримки зі сторони державного регулювання.

Актуальність дослідження теми МСП передусім продиктована необхідністю узагальнення раніше досліджених пластів цієї теми, появою нових реформ та прагненням України вдосконалити економічну систему та вивести її на світовий рівень.

Розвиток економіки залежить не лише від внутрішніх принципів ведення політики, але і від зовнішніх факторів, що впливають на стан світової економіки. Початок 2020 року змусив керівників країн світової спільноти задуматися про принципи збереження економічних показників у період тригеру, викликаного пандемією коронавірусу та обвалом цін на нафту, а тому цілком закономірною $є$ практика впровадження програм щодо підтримки підприємств малого та середнього бізнесу в період рецесії світової економіки.

Ключові слова: види підприємств, малі та середні підприємства, національне підприємництво, підприємництво, роль малого та середнього підприємництва, суб'єкти господарювання.

JEL Codes: D04, M21, 012

Tables: 5; Figures: 3; References: 15

Language of the article: English 
Daria D. Tymoshyk, Larysa L. Hrytsenko, Yaroslav S. Kovalev Small and Medium Entrepreneurship: Ukrainian and World Experience

Jimepamypa

1. Варналій, 3. Політико-правове регулювання підприємництва в Україні: теорія і практика: Монографія / З. Варналій, В. Кампо. - Київ : Знання, 2005. - 380 с.

2. Варналій, 3. Основи підприємництва : навч. посібн. / 3. Варналій. - Київ : Знання, 2002. - 239 с.

3. Макконнелл, К. Р., Брю, С. Л. Экономикс : принципы, проблемы и политика. - Москва : ИНФРА-М, 2003. - 972 с.

4. Шумпетер, Й. Теория экономического развития / пер. с англ. В. С. Автономова. - Москва : Директмедиа Паблишинг, 2008. - 401 с.

5. Долан, Э. Дж. Микроэкономика / Э. Дж. Долан, Д. Линдсей. - Санкт-Петербург, 1994. - 448 с.

6. Закон України «Про підприємництво» [Електронний ресурс]. - Режим доступу : https://zakon.rada.gov.ua/laws/show/698-12

7. Господарський кодекс України [Електронний ресурс]. - Режим доступу : https://zakon.rada.gov.ua/laws/show/436-15

8. Тринько Р. Державне регулювання підприємництва : теорія, методика, практика / Р. Тринько, О. Маліновська. - Львів : Львівський державний університет внутрішніх справ, 2007. - 184 с.

9. Основи економічної теорії : навч. посіб. - Ч. 3: Підприємництво в ринковій економіці / за ред. Ю. В. Ніколенка. - Київ : НМК ВО, 1992. - 350 с.

10. Варналій, 3. Мале підприємництво: основи теорії і практики / 3. Варналій - Київ : Знання, 2008. $-302 \mathrm{c}$.

11. Економіка і підприємництво, менеджмент: навч. посіб. / С. Рогач, Т. Гуцул, В. Ткачук та ін. Київ : Видавничий центр НУБіП України, 2015. - 726 с.

12. Закон України про внесення змін до Закону України «Про бухгалтерський облік та фінансову звітність в Україні» щодо удосконалення деяких положень [Електронний ресурс]. - Режим доступу : https://zakon.rada.gov.ua/laws/show/2164-19

13. Рекомендація Комісії від 6 травня 2003 року про визначення мікро-, малих та середніх підприємств [Електронний ресурс]. - Режим доступу : https://minjust.gov.ua/m/str_45877

14. Малий бізнес та підприємництво в ринкових умовах господарювання / Л. Воротіна, В. Воротін, Л. Мартинюк, Т. Черняк. - Київ : Видавництво Європейського університету, 2002. - 307 с.

15. Державна служба статистики України [Електронний ресурс]. - Режим доступу : http://ukrstat.gov.ua 